\title{
ANTIBIOTIKŲ VARTOJIMO VIRŠUTINIŲ KVĖPAVIMO TAKŲ INFEKCIJŲ GYDYMUI YPATUMAI: VISUOMENĖS ŽINIŲ IR SAVIGYDOS IVERTINIMAS
}

\author{
Karolina Dubickaitė, Ieva Merkytė, Eglė Pavydė, Audrius Sveikata \\ Lietuvos sveikatos mokslu universiteto Fiziologijos ir farmakologijos institutas
}

Raktažodžiai: antibiotikai, visuomenès žinios, neracionalus antibiotikų vartojimas, savigyda

\section{Santrauka}

Neracionalus antibiotikų vartojimas viršutinių kvèpavimo takų infekcijoms gydyti ir savigyda antibiotikais - svarbios visuomenès sveikatos problemos. Lietuvoje atlikta mažai tyrimų, kurie vertintų visuomenès žinias apie antibiotikus. Šio tyrimo tikslas buvo ịvertinti antibiotikų vartojimo ypatumus, visuomenès žinias, elgesị vartojant šiuos vaistus, savigydos paplitimą, priežastis. Perspektyviniam momentiniam stebejimo tyrimui atlikti pasirinktas anoniminès apklausos metodas. Tyrimo instrumentas - originalus klausimynas, sudarytas iš 20 klausimų. Aprašomoji ir lyginamoji statistinè duomenų analizė atlikta statistiniu paketu SPSS Statistics 17.0. Rezultatai laikyti statistiškai patikimais, kai $\mathrm{p}<0,05$. Nors antibiotikai yra dažnai vartojami vaistiniai preparatai, tačiau visuomenès žinios apie juos nèra pakankamos. Net ketvirtadalis respondentų $(27,2$ proc.) mane, kad antibiotikai veikia virusų sukeltas infekcijas, pusè - kad antibiotikai vienodai veikia tiek bakterijų, tiek virusų sukeltas infekcijas. Daugianarè logistinè regresinè analizè atskleidè, kad silpnos žinios apie antibiotikus buvo susijusios su dažnesniu šių vaistinių preparatų vartojimu ( $\mathrm{p}=0,005$; $\mathrm{OR}=2,959 ; 95 \%$ CI 1,389-6,307) ir didesne rizika užsiimti savigyda ( $\mathrm{p}=0,024 ; \mathrm{OR}=1,816 ; 95 \% \mathrm{CI}$ 1,082-3,046). Savigydos antibiotikais paplitimas tarp tiriamujų buvo 38,0 proc. Savigydą antibiotikais skatina tai, kad šių vaistinių preparatų vis dar galima įsigyti be recepto. Gydytojai ir vaistininkai turètu skirti daugiau laiko konsultuodami pacientus apie racionalų antibiotikų vartojimą prieš išduodami šiuos vaistinius preparatus.
Ivadas

Neracionalus antibiotikų vartojimas ir sparčiai besivystantis antimikrobinis rezistentiškumas yra rimtos visuomenès sveikatos problemos [1]. Neracionalų antibiotikų vartojimą lemia daugybė priežasčių. Anksčiau atlikti tyrimai parodè, kad neracionalus antibiotikų vartojimas yra glaudžiai susijęs su prastomis visuomenès žiniomis apie šiuos vaistinius preparatus [2-4]. Kitas veiksnys, lemiantis vis didejantị neracionalų antibiotikų vartojimą, yra savigyda antibiotikais, t.y. antimikrobinių vaistu ịsigijimas be recepto ar jų vartojimas be gydytojo nurodymo [5]. Viena dažniausių neracionalaus antibiotikų vartojimo priežasčių yra viršutinių kvėpavimo takų infekcijos. Europoje savigydos antibiotikais paplitimas svyruoja nuo 5 iki 45 proc. [3,6-14]. Lietuvoje atliktų studijų duomenimis nustatyta, kad savigyda antibiotikais šalyje gali siekti apie 30 proc. [13-14].

Kita neracionalaus antibiotikų vartojimo priežastis yra gydytojo nurodymų nesilaikymas. Sergant viršutinių kvèpavimo takų infekcijomis, dažnai antibiotikų vartojimas būna nutraukiamas per anksti, o antibiotikų likutis paliekamas namų vaistinėleje. Tai rodo, kad visuomenè nèra gerai informuota, kaip reikia tinkamai utilizuoti likusius nesuvartotus vaistinius preparatus.

Iki šiol Lietuvoje atlikta mažai tyrimų, kurie vertintų visuomenès žinias apie antibiotikų vartojimą viršutinių kvèpavimo takų infekcijoms gydyti bei elgesi juos vartojant [14-16]. Sparčiai augantys antimikrobinio rezistentiškumo mastai, neracionalus vartojimas ir dažnai praktikuojama savigyda antibiotikais parodo poreikị tyrinèti su šia vaistų grupe susijusius aspektus Lietuvoje ir pabrèžia nagrinèjamų problemų aktualumą.

Tyrimo tikslas - įvertinti antibiotikų vartojimo ypatumus viršutinių kvėpavimo infekcijų gydymui, visuomenès žinias apie šiuos vaistinius preparatus bei savigydos antibiotikais paplitimą. 


\section{Tyrimo objektas ir metodai}

$2014 \mathrm{~m}$. rugsèjo - $2016 \mathrm{~m}$. vasario mèn. Lietuvos sveikatos mokslų universiteto (LSMU) ligoninès Kauno klinikų Centrinejje konsultacinejje poliklinikoje atliktas perspektyvinis momentinis stebejjimo tyrimas. Tyrimui atlikti pasirinktas anoniminès apklausos metodas. Prieš tyrimą buvo gautas LSMU Bioetikos centro leidimas (Nr. 2014/ BEC-FF-42; $2014 \mathrm{~m}$. spalio $10 \mathrm{~d}$.). I tyrimą buvo įtraukti ne jaunesni nei 18 metų amžiaus asmenys, kurie tyrimo metu lankèsi LSMU ligoninès Kauno klinikų Centrinėje konsultacineje poliklinikoje, sutiko dalyvauti tyrime ir pasirašè informuoto sutikimo formą.

Tyrimo instrumentas - originalus klausimynas, sudarytas iš 4 dalių, 20 klausimų. Pirmojoje dalyje respondentu buvo prašoma pateikti demografinius duomenis (amžius, lytis, gyvenamoji vieta, išsilavinimas, vidutinès mènesio pajamos, tenkančios vienam šeimos nariui). Antrojoje klausimyno dalyje vertintas antibiotikų vartojimas ir elgesys ju vartojimo metu. Pateikti klausimai siekiant išsiaiškinti, ar respondentas yra vartojęs antibiotikus viršutinių kvẻpavi-

1 lentelè. Tiriamųjų charakteristikos $(n=461)$

\begin{tabular}{|l|c|}
\hline \multicolumn{1}{|c|}{ Charakteristikos } & n (proc.) \\
\hline Amžius: 18-29 & $143(31,0)$ \\
\hline $30-39$ & $75(16,3)$ \\
\hline $40-49$ & $93(20,2)$ \\
\hline $50-59$ & $82(17,8)$ \\
\hline$\geq 60$ & $68(14,8)$ \\
\hline Moterys & $292(63,3)$ \\
\hline Gyvenamoji vieta: miestas & $352(76,4)$ \\
\hline Išsilavinimas: & \\
\hline Vidurinis ar žemesnis & $160(34,7)$ \\
\hline Aukštesnysis & $102(22,1)$ \\
\hline Aukštasis & $199(43,2)$ \\
\hline Vidutinės pajamos: $<500$ Eur & $88(19,1)$ \\
\hline $500-1000$ Eur & $129(28,0)$ \\
\hline$>1000$ Eur & $244(52,3)$ \\
\hline
\end{tabular}

mo takų infekcijų gydymui, kaip dažnai tenka vartoti antibiotikus, kokius antibiotikus vartojo respondentai. Taip pat buvo klausiama, kas yra pagrindinis antibiotikų vartojimo informacijos šaltinis, ar gydytojai/vaistininkai suteikia pakankamai informacijos skirdami/išduodami antibiotikus, pateiktas klausimas, ką respondentai daro su likusiais nesuvartotais antibiotikais. Trečioji klausimyno dalis buvo skirta įvertinti apklaustujų žinias apie antibiotikus, jų vartojimo ypatumus. Ketvirtojoje dalyje vertinti su savigyda antibiotikais susiję aspektai.

Reikiamas imties dydis buvo apskaičiuotas naudojant Raosoft skaičiuotuvą. Esant $95 \%$ tikimybei ir 5\% paklaidai, $80 \%$ atsako pasiskirstymui apskaičiuotas reikiamas imties dydis - 246 respondentai.

Aprašomoji ir lyginamoji statistinè duomenų analizė atlikta statistiniu paketu SPSS Statistics 17.0. Siekiant nustatyti rizikos veiksnius, susijusius su silpnomis žiniomis apie

2 lentelè. Antibiotikų vartojimo dažnis

\begin{tabular}{|l|c|}
\hline \multicolumn{1}{|c|}{ Vartojimo dažnis } & n (proc.) \\
\hline Nevartojo & $119(25,8)$ \\
\hline Bent kartą per pusę metų & $39(8,4)$ \\
\hline Bent kartą per metus & $81(17,6)$ \\
\hline Rečiau nei kartą per metus & $222(48,2)$ \\
\hline
\end{tabular}

3 lentelè. Respondentų žinios apie antibiotikus ir jų vartojimą

*Pateiktas respondentu, pritarusiu teiginiams, skaičius ir procentine dalis

\begin{tabular}{|l|c|}
\hline \multicolumn{1}{|c|}{ Teiginys } & $\begin{array}{c}\text { n } \\
\text { (proc.)* }\end{array}$ \\
\hline $\begin{array}{l}\text { Antibiotikai veikia bakterijų su- } \\
\text { keltas infekcijas }\end{array}$ & $\begin{array}{c}101 \\
(21,9)\end{array}$ \\
\hline $\begin{array}{l}\text { Antibiotikai veikia virusų su- } \\
\text { keltas infekcijas }\end{array}$ & $\begin{array}{c}125 \\
(27,2)\end{array}$ \\
\hline $\begin{array}{l}\text { Antibiotikai veikia ir bakterijų, } \\
\text { ir virusų sukeltas infekcijas }\end{array}$ & $\begin{array}{c}223 \\
(50,9)\end{array}$ \\
\hline $\begin{array}{l}\text { Antibiotikus turi paskirti gydy- } \\
\text { tojas }\end{array}$ & $\begin{array}{c}417 \\
(90,5)\end{array}$ \\
\hline $\begin{array}{l}\text { Antibiotikus galima vartoti sa- } \\
\text { varankiškai }\end{array}$ & $\begin{array}{c}360 \\
(78,1)\end{array}$ \\
\hline $\begin{array}{l}\text { Antibiotikus reikia vartoti tiek } \\
\text { dienų, kiek nurodè gydytojas }\end{array}$ & $\begin{array}{c}217 \\
(47,1)\end{array}$ \\
\hline $\begin{array}{l}\text { Antibiotikų vartojimą galima } \\
\text { nutraukti pasijutus geriau }\end{array}$ & $\begin{array}{c}334 \\
(72,5)\end{array}$ \\
\hline $\begin{array}{l}\text { Žinojo teriminą „Antibiotikų } \\
\text { rezistentiškumas“ }\end{array}$ & $\begin{array}{c}128 \\
(27,8)\end{array}$ \\
\hline
\end{tabular}


antibiotikus, atlikta daugianarè logistinė regresiné analizé, apskaičiuoti galimybių santykiai (OR) ir pasikliautinumo intervalai $(95 \% \mathrm{CI})$. Rezultatai laikyti statistiškai patikimais, kai patikimumo koeficientas $\mathrm{p}<0,05$.

\section{Rezultatai}

I tyrimo analizę buvo įtraukti 461 iš 600 klausimynu (atsakomumo dažnis 76,8 proc.), kurie buvo grąžinti, pilnai užpildyti ir atitiko įtraukimo kriterijus. Respondentų amžiaus vidurkis buvo 40,2 $\pm 15,3$ (intervalas 18-86 metai), daugiau nei trečdali apklaustujų sudarè vyrai (36,7 proc.). Dauguma apklaustujų gyveno miestuose (76,4 proc.). I tyrimą įtraukti skirtingo išsilavinimo lygio bei skirtingas vidutines mènesio pajamas gaunantys respondentai. Tiriamujų charakteristikos pateiktos 1 lenteleje.

Antibiotikus anksčiau nurodè vartoję beveik trys ketvirtadaliai (74,2 proc.) apklaustujų. Antibiotikus bent kartą per metus ir dažniau vartojo kiek daugiau nei ketvirtadalis apklaustujų (26,0 proc.). Antibiotikų vartojimo dažnis pateiktas 2 lentelëje. Dažniausiai viršutinių kvẻpavimo takų infekcijoms gydyti vartotas antibiotikas buvo amoksicilinas. Jị nurodè vartoję 39,6 proc. respondentų. Beveik trečdalis apklaustujų (32,6 proc.) negalèjo ịvardinti anksčiau vartotų antibiotikų pavadinimo arba nurodè kitoms vaistų grupéms priskiriamus vaistus.

İdomu tai, kad kaip pagrindini informacijos apie antibiotikus šaltinị respondentai ịvardijo vaistininką ( 80,5 proc.), kiek daugiau nei puse nurodė gydytoją (57,5 proc.) (buvo galima rinktis daugiau nei vieną atsakymo variantą). Taip pat šiek tiek daugiau respondentų nurodè, kad vaistininko konsultacija išduodant antibiotikus buvo pakankamai išsami ir naudinga (63,2 roc.) lyginant su gydytojo konsultacija skiriant antibiotikus (60,3 proc.).

Siekiant ivvertinti tiriamujų žinias apie antibiotikus, jiems buvo pateikti teiginiai apie šiuos vaistinius preparatus. Respondentai turejo nurodyti, ar teiginys yra teisingas. Respondentų atsakymai pateikti 3 lentelèje.

Net ketvirtadalis respondentu (27,2 proc.) manè, kad antibiotikai veikia virusu sukeltas infekcijas, pusè respondentu ivardijo, kad antibiotikai vienodai veikia tiek bakterijų, tiek virusų sukeltas infekcijas. Nors didžioji dalis respondentų (90,5 proc.) supranta, kad antibiotikus turètuc paskirti gydytojas, daugelis jų (78,1 proc.) taip pat pritarè teiginiui, kad antibiotikus galima vartoti savarankiškai. Be to, tik pusè respondentų manè, kad antibiotikus reikia vartoti tiek dienų, kiek paskyre gydytojas. Tai rodo, kad respondentai gydytojo vaidmeni skiriant antibiotikus vertina tik kaip sveikatos priežiūros specialisto, kuris išrašo reikiamą receptą.

Daugianarè logistinè regresinė analizė atskleidè, kad silpnos žinios apie antibiotikus buvo susijusios su dažnesniu šių vaistinių preparatų vartojimu (bent kartą per pusę metu; $\mathrm{p}=0,005 ; \mathrm{OR}=2,959 ; 95 \%$ CI 1,389-6,307) ir didesne rizika užsiimti savigyda antibiotikais $(\mathrm{p}=0,024 ; \mathrm{OR}=1,816$; 95\% CI 1,082-3,046). Žinių apie antibiotikus lygis nebuvo susijęs su respondentų lytimi, amžiumi, gyvenamaja vieta, išsilavinimu ar pajamomis.

Savigydos antibiotikais paplitimas tarp tiriamujų buvo 38,0 proc. Kiek daugiau nei pusė antibiotikus vartojusių respondentų (51,2 proc.) nurodè, kad yra ịsigiję antibiotikų be recepto ar vartoje juos be gydytojo nurodymo. Pagrindiniai tokių antibiotikų šaltiniai buvo jų likutis namų vaistinèlëje (35,7 proc.) bei antibiotikai, įsigyti vaistinèje be recepto (21,3 proc.). Beveik pusè respondentų ( 44,7 proc.) nesuvartotus antibiotikus pasilieka namų vaistinèlëje.

\section{Rezultatų aptarimas}

Šis tyrimas atskleidè nepakankamas visuomenès žinias apie antibiotikus. Visuomenè yra linkusi nesilaikyti gydytojų rekomendacijų ir gydytis savarankiškai. Silpnos žinios apie antibiotikus ir nesuvokimas, kad neracionalus antibiotikų vartojimas kelia grèsmę sveikatai bei didina antimikrobinį rezistentiškumą, skatina dažnesnị, nereikalingą antibiotikų vartojimą ir savigydą šiais vaistiniais preparatais. Mūsų tyrimo rezultatai yra palyginami su anksčiau Lietuvoje atliktomis studijomis [13-16].

Savigyda antibiotikais Lietuvoje išlieka rimta visuomenès sveikatos problema. Remiantis tyrimo rezultatais, silpnos žinios apie antibiotikus beveik du kartus $(\mathrm{OR}=1,816)$ padidina riziką, kad žmogus užsiims savigyda ir nesikreips i sveikatos priežiūros specialistus. Savigydos paplitimas tarp tiriamujų buvo net 38,0 proc. Šis rodiklis yra palyginamas su kitų Europos Sajungos šalių savigydos antibiotikais paplitimu, tokiu kaip Graikija (44,6 proc.) [11] ar Lenkija (41,4 proc.) [9]. Tačiau reiketų paminèti ir tai, kad antibiotikų suvartojimas (išreikštas apibrèžta dienos doze 1000 gyventojų per dieną - angl. defined daily doses; DDD) Lietuvoje $(19,72)$ buvo reikšmingai mažesnis nei Lenkijoje $(23,59)$ ir Graikijoje $(38,64)[19]$.

Savigydą antibiotikais Lietuvoje gali skatinti ir jų prieinamumas visuomenès vaistinèse. Mūsų tyrimo rezultatai rodo, kad daugiau nei pusė antibiotikus vartojusių respondentų yra ịsigiję antibiotikų be recepto arba vartoję juos be gydytojo nurodymo. Vienas pagrindinių antibiotikų įsigijimo be recepto šaltinių buvo visuomenès vaistinès ( 21,3 proc.). Tai rodo, kad Lietuvos sveikatos priežiūros sistema ir ypač visuomeninès vaistinès turètų dar griežčiau kontroliuoti receptinių vaistų pardavimą. Taip pat visuomenè turètų būti geriau informuota, ką daryti su likusiais nesuvartotais vaistais, norint suma- 
žinti savigydą antibiotikais, likusiais namų vaistinèlèse.

Neracionalus antibiotiku vartojimas ir dideli savigydos mastai rodo poreikị plataus spektro švietimo intervencijoms plètoti bei iggyvendinti skirtingose visuomenès grupèse. Tyrimais įrodyta nacionalinių, regioninių švietimo programų ir viešų kampanijų įtaka, visuomenès supratimo ir žinių apie antibiotikus didinimui [20]. Ši priemonè turètų būti svarstoma kompetentingų sveikatos priežiūros institucijų, siekiant skatinti racionalų antibiotikų vartojimą Lietuvoje.

\section{Išvados}

1. Visuomenès žinios apie antibiotikus ir jų racionalų vartojimą yra nepakankamos.

2. Savigyda antibiotikais yra plačiai paplitęs reiškinys, galintis nulemti neracionalų šių vaistų vartojimą.

3. Antibiotiku vis dar galima ịsigyti be recepto Lietuvos visuomenès vaistinèse, todèl ị šių vaistų prieinamumą ir jų išdavimo kontrolę turètų būti atkreiptas didesnis kompetentingų institucijų dẻmesys.

4. Gydytojai ir vaistininkai, skirdami ar išduodami antibiotikus, turètų skirti daugiau laiko konsultuodami pacientus apie racionalų šių vaistinių preparatų vartojimą.

\section{Literatūra}

1. WHO. World Health Day 2011, Policy Briefs.

2. Chan YH, Fan MM, Fok CM, Lok ZL, Ni M, Sin CF, Wong KK, Wong SM, Yeung R, Yeung TT, Chow WC, Lam TH, Schooling CM. Antibiotics nonadherence and knowledge in a community with the world's leading prevalence of antibiotics resistance: Implications for public health intervention. Amer. J. Infect. Control 2012; 40:113-117.

http://dx.doi.org/10.1016/j.ajic.2011.03.017

3. McNulty CA, Boyle P, Nichols T, Clappison P, Davey P. Don't wear me out-The public's knowledge of and attitudes to antibiotic use. J. Antimicrob. Chemother 2007; 59: 727-738.

http://dx.doi.org/10.1093/jac/dk1558

4. You JHS, Yau B, Choi KC, Chau CTS, Huang QR, Lee SS. Public knowledge, attitudes and behavior on antibiotic use: A telephone survey in Hong Kong. Infection 2008; 36:153-157. http://dx.doi.org/10.1007/s15010-007-7214-5

5. Awad AI, Aboud EA. Knowledge, Attitude and practice towards antibiotic use among the public in Kuwait. PLoS ONE 2015; 10. http://dx.doi.org/10.1371/journal.pone.0117910

6. Napolitano F, Izzo MT, di Giuseppe G, Angelillo IF. Public knowledge, attitudes, and experience regarding the use of antibiotics in Italy. PLoS ONE 2013; 8.

http://dx.doi.org/10.1371/journal.pone.0084177

7. Ivanovska $\mathrm{V}$, Zdravkovska M, Bosevska G, Angelovska B. Antibiotics for upper respiratory infections: Public knowledge, beliefs and self-medication in the Republic of Macedonia. Prilozi 2013; 34:59-70.
8. Väänänen MH, Pietilä K, Airaksinen M. Self-medication with antibiotics - Does it really happen in Europe? Health Policy 2006; 77:166-171.

http://dx.doi.org/10.1016/j.healthpol.2005.07.001

9. Muras M, Krajewski J, Nocun M, Godycki-Cwirko M. A survey of patient behaviours and beliefs regarding antibiotic self-medication for respiratory tract infections in Poland. Arch. Med. Sci 2013; 9: 854-857.

http://dx.doi.org/10.5114/aoms.2012.29217

10. Damian L, Lupuşoru CE, Ghiciuc CM. Self-medication with antimicrobial drugs among university students in a northeast region of Romania. Rev. Med. Chir. Soc. Med. Nat. Iasi 2014; 118: $160-164$.

11. Skliros E, Merkouris P, Papazafiropoulou A, Gikas A, Matzouranis G, Papafragos C, Tsakanikas I, Zarbala I, Vasibosis A, Stamataki P, Sotiropoulos A. Self-medication with antibiotics in rural population in Greece: A cross-sectional multicenter study. BMC Fam. Pract 2010; 11.

http://dx.doi.org/10.1186/1471-2296-11-58

12. Ilhan MN, Durukan E, Ilhan SO, Aksakal FN, Ozkan S, Bumin MA. Self-medication with antibiotics: Questionnaire survey among primary care center attendants. Pharmacoepidemiol. Drug Saf 2009; 18:1150-1157.

http://dx.doi.org/10.1002/pds.1829

13. Berzanskyte A, Valinteliene R, Haaijer-Ruskamp F.M, Gurevicius R, Grigoryan L. Self-medication with antibiotics in Lithuania. Int. J. Occup. Med. Environ. Health 2006; 19:246-253. http://dx.doi.org/10.2478/v10001-006-0030-9

14. Pavydė E, Veikutis V, Mačiulienė A, Mačiulis V, Petrikonis $\mathrm{K}$, Stankevičius E. Public knowledge, beliefs and behavior on antibiotic use and self-medication in Lithuania. Int J Environ Res Public Health 2015; 12:7002-16.

http://dx.doi.org/10.3390/ijerph120607002

15. Grigoryan L, Burgerhof JGM, Degener JE, Deschepper R, Lundborg CS, Monnet DL, Scicluna EA, Birkin J, Haaijer-Ruskamp FM, SAR consortium. Attitudes, beliefs and knowledge concerning antibiotic use and self-medication: A comparative European study. Pharmacoepidemiol. Drug Saf 2007; 16:1234-1243.

http://dx.doi.org/10.1002/pds.1479

16. Godycki-Cwirko M, Cals JWL, Francis N, Verheij T, Butler CC, Goossens H, Zakowska I, Panasiuk L. Public beliefs on antibiotics and symptoms of respiratory tract infections among rural and urban population in Poland: A questionnaire study. PLoS ONE 2014; 9.

http://dx.doi.org/10.1371/journal.pone.0109248

17. Adriaenssens N, Coenen S, Versporten A, Muller A, Minalu G, Faes C, Vankerckhoven V, Aerts M, Hens N, Molenberghs G, Goossens H, ESAC Project group european surveillance of antimicrobial consumption (ESAC): outpatient antibiotic use in Europe (1997-2009) J. Antimicrob. Chemother 2011:66, 3-12. 


\section{ANTIBIOTICS FOR THE TREATMENT OF UPPER RESPIRATORY TRACT INFECTIONS: ASSESSMENT OF PUBLIC KNOWLEDGE AND SELF-MEDICATION}

\section{K. Dubickaitė, I. Merkytė, E. Pavydė, A. Sveikata}

Key words: antibiotics, public knowledge, irrational antibiotic use, self-medication.

\section{Summary}

Irrational use of antibiotics for upper respiratory tract infections and self-medication are serious public health problems. Previous studies performed in Lithuania in order to evaluate public knowledge of antibiotics are rare. The aim of this study was to assess antibiotic usage patterns, public knowledge, behaviour and self-medication among Lithuanian public. The perspective cross-sectional study was performed using original anonymous questionnaire consisting of 20 questions. Descriptive and comparative statistical data analysis was processed with SPSS 17.0. Results were considered statistically significant as $p<0.05$. Even though antibiotics are commonly used medicinal products, public knowledge of antibiotics is insufficient. Over a quarter of respon- dents $(27.2 \%)$ believed that antibiotics are effective against viral infections, half of respondents stated that antibiotics are equally effective against bacterial and viral infections. Multivariate logistic regression analysis showed that poor knowledge of antibiotics was associated with frequent use of these medicinal products $(\mathrm{p}=0.005$; $\mathrm{OR}=2.959 ; 95 \%$ CI 1.389-6.307) and higher risk of self-medication with antibiotics $(\mathrm{p}=0,024 ; \mathrm{OR}=1.816 ; 95 \%$ CI 1.082-3.046). The prevalence of self-medication was about $38.0 \%$. Self-medication rate may be influenced by the fact that there is still a possibility to obtain antibiotics without prescription. Physicians and pharmacists should spend more time consulting patients about rational use of antibiotics while prescribing or dispensing these medications.

Correspondence to: ieva.merkyte91@gmail.com

Gauta 2016-03-18 